\title{
Optimization of biomass and astaxanthin production by the yeast Phaffia rhodozyma
}

\author{
Danilo Gomes Moriel' ${ }^{1}$ lara Maria Pereira Machado ${ }^{1}$, José Domingos Fontana ${ }^{2}$, \\ Tania Maria Bordin Bonfim ${ }^{1 *}$
}

${ }^{1}$ Laboratório de Enzimologia e Tecnologia das Fermentações, ${ }^{2}$ Biomass Chemo/Biotechnology Laboratory, Departamento de Farmácia, Universidade Federal do Paraná

\section{*Correspondência:}

T. M. B. Bonfim

Laboratório de Enzimologia e Tecnologia

das Fermentações,

Departamento de Farmácia,

Universidade Federal do Paraná

Rua Lothário Meissner, 3400

80210-170, Curitiba, Paraná, Brasil

e-mail: moriel@bol.com.br
The combination of fed-batch processes and low cost substrates (sugar cane juice and urea) was studied in view of the optimization of biomass and astaxanthin production by the yeast Phaffia rhodozyma ATCC 24202. In the optimized process, a biomass and astaxanthin productivity of $0.327 \mathrm{~g} / \mathrm{l} / \mathrm{h}$ and $0.124 \mathrm{mg} / \mathrm{l} / \mathrm{h}$ was achieved, respectively. Compared to the batch process studied, an increase of approximately 4.55-fold in the biomass productivity and 4.73-fold in the astaxanthin productivity was found.

\section{Uniterms:}

- Astaxanthin

- Biomass

- Fed-batch processes

- Low cost substrates

- Phaffia rhodozyma

\section{INTRODUCTION}

Astaxanthin (3,3'-dihydroxy- $\beta, \beta^{\prime}$-carotene-4,4'dione, Figure 1) is a carotenoid widely distributed in nature, being found as the main pigment in some crustaceans (shrimp and lobster), fish (trout and salmon), birds (flamingo and scarlet ibis) and microorganisms (the yeast Phaffia rhodozyma and the algae Haematococcus pluvialis) (Johnson, An, 1991).
Astaxanthin is mainly used in the trout and salmon farming. Since these animals can not synthesize carotenoids, pigments must be supplemented to their feeds, allowing their assimilation and providing the characteristic pigmentation of these fish, increasing the quality and consumer acceptance in the marketplace (Johnson, An, 1991).

Because of the increasing worldwide market, the high cost of synthetic astaxanthin and the need of astaxanthin obtained from natural sources, in scaled-up

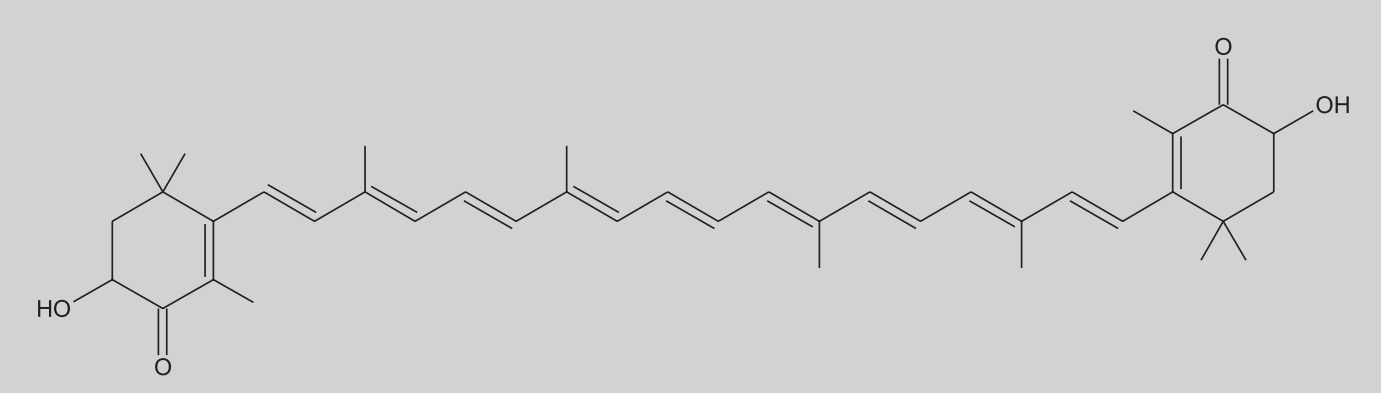

FIGURE 1 - Astaxanthin 
processes, at low cost and high productivity, several low cost substrates have been used as substrate for the cultivation of the yeast $P$. rhodozyma, like peat hydrolysate (Acheampong, Martin, 1995), wood hydrolysates (Cruz, Parajó, 1998; Parajó et al., 1997; Parajo, Santos, Vazquez, 1998; Vazquez, Santos, Parajo, 1998), corn wet-milling coproducts (Hayman, Mannarelli, Leathers, 1995) and even sugar cane juice (Chociai et al., 2002). In this way, the aim of this work is to optimize the biomass and astaxanthin production by the yeast $P$. rhodozyma, using fed-batch fermentation processes and low cost substrates (sugar cane juice and urea) as substrates.

\section{MATERIAL AND METHODS}

\section{Microorganism}

The microorganism used was the wild strain Phaffia rhodozyma ATCC 24202.

\section{Inoculum}

The inoculum was grown on a medium consisting of $20 \mathrm{~g}$ sucrose/L, $1 \mathrm{~g}$ yeast extract/L and $5 \mathrm{~g}$ peptone/L. The inoculum was cultivated in $250 \mathrm{~mL}$ erlenmeyer flasks in a rotatory shaker at $150 \mathrm{rpm}, 24^{\circ} \mathrm{C}$ for $48 \mathrm{~h}$. This culture was used to inoculate the batch and fed-batch processes in order to produce an initial absorbance in the fermentation medium of about $0.200(650 \mathrm{~nm})$.

\section{Bioreactor set-up}

Batch and fed-batch cultures were grown in a $21 \mathrm{~B}$.
Braun Biotech B bioreactor. The initial composition of the fermentation medium was sugar cane juice ( $20 \mathrm{~g}$ total carbohydrates/L) and urea $(1 \mathrm{~g} / \mathrm{L})$. The $\mathrm{pH}$ was controlled at $\mathrm{pH} 6.0 \pm 0.2$ by the automatic addition of $1 \mathrm{M} \mathrm{NaOH}$ and $1 \mathrm{M} \mathrm{H}_{2} \mathrm{SO}_{4}$. The aeration was maintained in $1 \mathrm{vvm}$ and the agitation was manually controlled in order to maintain the dissolved oxygen concentration above $40 \%$. The temperature was controlled at $24 \pm 0.5^{\circ} \mathrm{C}$. In the fed-batch process, feeding was done continuously between 24 and 72 $\mathrm{h}$ of the process, with sugar cane juice ( $250 \mathrm{~g}$ total carbohydrates/L), in order to keep the concentration of total carbohydrates in the fermentation medium of about 20 $\mathrm{g} / \mathrm{L}$ during the feeding. All experiments were done in duplicate and the average values of the results are shown.

\section{Analytical methods}

Total carbohydrates were measured by the phenolsulfuric method (Dubois et al., 1956). The biomass concentration was measured as optical density (OD) using spectrophotometry at $650 \mathrm{~nm}$ in all fermentation samples. At the end of the processes, biomass was determinated by freeze-drying the sample until constant weight. The astaxanthin content was determinated by the method described by Bonfim (1999).

\section{RESULTS AND DISCUSSION}

In order to increase the astaxanthin and biomass productivities, the yeast $P$. rhodozyma was cultivated in fed-batch process. Figures 2 and 3 show the substrate variation and biomass formation in the batch and fed-batch cultivation of the yeast $P$. rhodozyma, respectively.

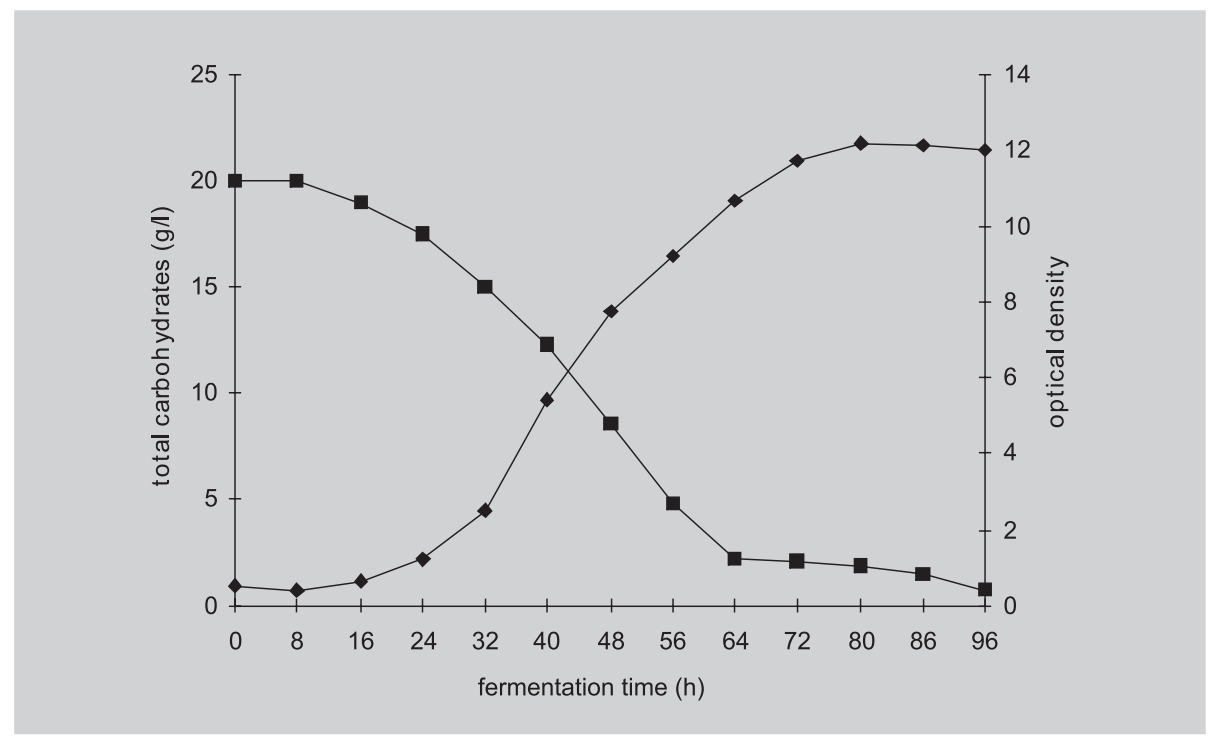

FIGURE 2 - Substrate consumption and biomass formation in the batch process. ( density 


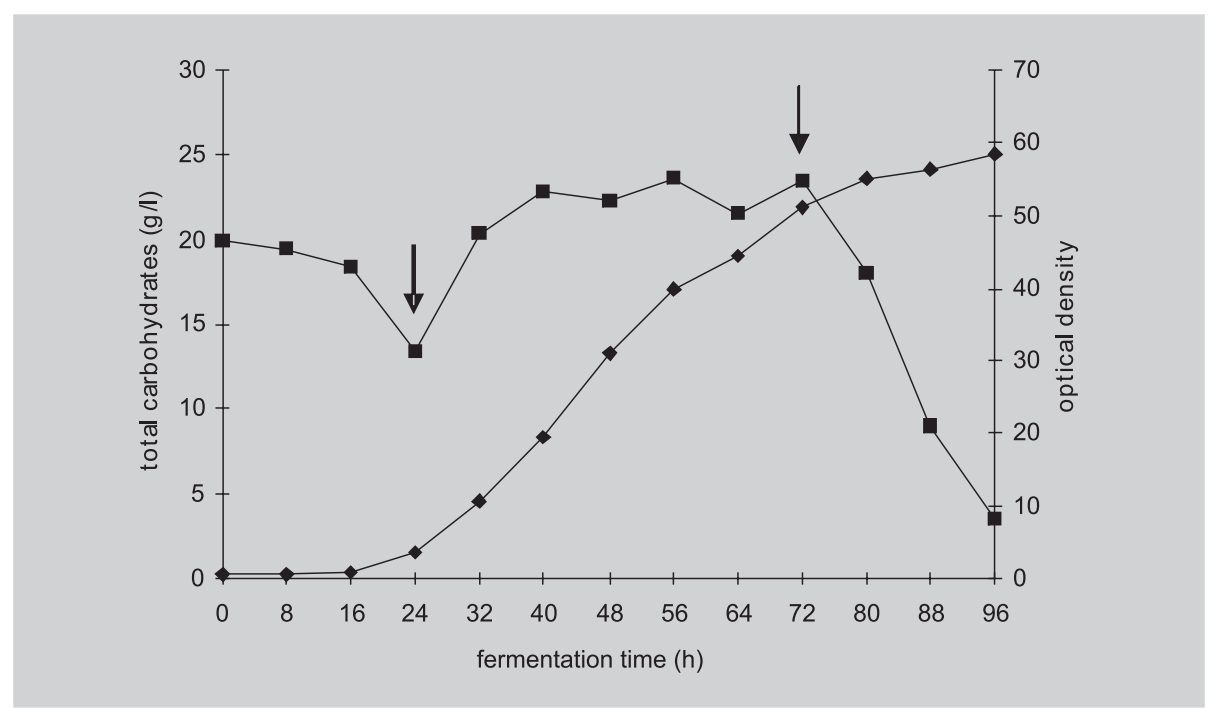

FIGURE 3 - Substrate variation and biomass formation in the fed-batch process.

total carbohydrates;

optical density; the arrows indicate the start and the end of the feeding.

TABLE I - Batch and fed-batch process results

\begin{tabular}{lccccccc}
\hline PROCESS & $\mathbf{X}$ & $\mathbf{P}$ & $\mathbf{P}_{\mathrm{p} / \mathbf{x}}$ & $\mathbf{P}_{\mathrm{x}}$ & $\mathbf{P}_{\mathrm{p}}$ & $\mathbf{Y}_{\mathrm{x} / \mathrm{s}}$ & $\mathbf{Y}_{\mathrm{p} / \mathrm{s}}$ \\
\hline Batch & 6.9 & 2.52 & 364.59 & 0.072 & 0.026 & 0.36 & $1.31 \times 10^{-4}$ \\
Fed-batch & 31.4 & 11.91 & 379.18 & 0.327 & 0.124 & 0.39 & $1.46 \times 10^{-4}$ \\
\hline
\end{tabular}

$\mathrm{X}$ : biomass yield (g/L); P: astaxanthin yield $(\mathrm{mg} / \mathrm{L}) ; \mathrm{P}_{\mathrm{p} / \mathrm{x}}$ : cellular concentration of astaxanthin ( $\mu \mathrm{g}$ astaxanthin/g biomass); $\mathrm{P}_{\mathrm{x}}$ : biomass productivity $(\mathrm{g} / \mathrm{L} / \mathrm{h}) ; \mathrm{P}_{\mathrm{p}}$ : astaxanthin productivity $(\mathrm{mg} / \mathrm{L} / \mathrm{h}) ; \mathrm{Y}_{\mathrm{x} / \mathrm{s}}$ : biomass yield from total carbohydrates consumed ( $\mathrm{g}$ biomass/g sugar consumed); $\mathrm{Y}_{\mathrm{p} / \mathrm{s}}$ : astaxanthin yield from total carbohydrates consumed ( $\mathrm{g}$ astaxanthin $/ \mathrm{g}$ sugar consumed).

Table I shows the results obtained in these two cultures. Comparing the fed-batch process to the batch process studied, the biomass $\left(\mathrm{P}_{\mathrm{x}}\right)$ and astaxanthin productivity $\left(\mathrm{P}_{\mathrm{p}}\right)$ increased approximately 4.55 and 4.73 fold, respectively, without losses in $\mathrm{Y}_{\mathrm{x} / \mathrm{s}}$ and $\mathrm{Y}_{\mathrm{p} / \mathrm{s}}$ (biomass and astaxanthin yield from total carbohydrates consumed, respectively), indicating that the substrate consumed by the yeast was not being used for ethanol production.

\section{CONCLUSIONS}

The use of a fed-batch fermentation is an important tool in process optimization and allows the establishment of high biomass and astaxanthin productivity processes. In this work, we optimized the production of biomass and astaxanthin productivities by fed-batch fermentation. Once this process is associated to low cost substrates, it could arouse interest to the industrial production, leading to a cost of about $\$ 0.53 / \mathrm{g}$ astaxanthin based on the carbon source price.

\section{RESUMO}

\section{Otimização da produção de biomassa e astaxantina pela levedura Phaffia rhodozyma}

A combinação de processos descontínuo alimentado e matérias-primas de baixo custo (caldo de cana-deaçúcar e uréia) foi estudada a fim de otimizar a produção de biomassa e astaxantina pela levedura Phaffia rhodozyma ATCC 24202. No processo otimizado, produtividades em biomassa e astaxantina de 0,327 $\mathrm{g} / \mathrm{L} /$ h e $0,124 \mathrm{mg} / \mathrm{L} / \mathrm{h}$ foram obtidas, respectivamente. Comparadas com o processo descontínuo estudado, verificou-se aumento de 4,55 vezes na produtividade em biomassa e 4,73 vezes na produtividade em astaxantina.

UNITERMOS: Astaxantina. Biomassa. Matérias-primas de baixo custo. Processo descontínuo alimentado. Phaffia rhodozyma. 


\section{REFERENCES}

ACHEAMPONG, E. A., MARTIN, A. M. Kinetic studies on the yeast Phaffia rhodozyma. J. Basic Microbiol., v. 35, p. $147-155,1995$.

BONFIM, T. M. B. Produção de astaxantina pela levedura Phaffia rhodozyma (Xanthophyllomyces dendrorhous) a partir de meios de cultura de baixo custo. Curitiba, 1999. 159 p. [Tese de doutorado: Universidade Federal do Paraná].

CHOCIAI, M. B.; MACHADO, I. M. P.; FONTANA, J. D.; CHOCIAI, J. G.; BUSATO, S. B.; BONFIM, T. M. B. Cultivo da levedura Phaffia rhodozyma (Xanthophyllomyces dendrorhous) em processo descontínuo alimentado para produção de astaxantina. Rev. Bras. Cien. Farm., v. 38, p. 457-462, 2002.

CRUZ, J. M.; PARAJO, J. C. Improved astaxanthin production by Xanthophyllomyces dendrorhous growing on enzymatic wood hydrolysates containing glucose and cellobiose. Food Chem., v. 63, p. 479-484, 1998.

DUBOIS, M.; GILLES, K. A.; HAMILTON, J. K.; REBERS, P. A.; SMITH, F. Colorimetric method for determination of sugars and related substances. Anal.Chem., v. 28, p. 350-356, 1956.
HAYMAN, G. T.; MANNARELLI, B. M.; LEATHERS, T. D. Production of carotenoids by Phaffia rhodozyma grown on media composed of corn wet-milling coproducts. J. Ind. Microbiol., v. 14, p. 389-395, 1995.

JOHNSON, E. A.; AN, G. H. Astaxanthin from microbial sources. Critical Rev. Biotechnol., v. 11, p. 297-326, 1991.

PARAJO, J. C.; SANTOS, V.; VÁZQUEZ, M.; CRUZ, J. M. Production of carotenoids by Xanthophyllomyces dendrorhous growing on enzymatic hydrolysates of prehydrolysed wood. Food Chem., v. 60, p. 347-355, 1997.

PARAJO, J. C.; SANTOS, V.; VAZQUEZ, M. Production of carotenoids by Phaffia rhodozyma growing on media made from hemicellulosic hydrolysates of Eucalyptus globulus wood. Biotechnol. Bioeng., v. 59, p. 501-506, 1998.

VAZQUEZ, M.; SANTOS, V.; PARAJO, J. C. Fed-batch cultures of Phaffia rhodozyma in xylose-containing media made from wood hydrolysates. Food Biotechnol., v. 12, p. $43-55,1998$.

Recebido para publicação em 27 de fevereiro de 2004. Aceito para publicação em 18 de outubro de 2004. 